\title{
CHEMINIAI AKIŲ NUDEGIMAI
}

\author{
Kristina Sauliūnaitė, Edita Puodžiuvienè \\ Lietuvos sveikatos moksly universitetas
}

Raktažodžiai: cheminiai akių nudegimai, akių cheminių nudegimų gydymas, cheminiai akių sužalojimai.

\begin{abstract}
Santrauka
Tikslas - išanalizuoti akių cheminių nudegimų epidemiologiją, klinikinès eigos ypatumus ir gydymo principus. Tyrimo metodas - sisteminè literatūros apžvalga. Mokslinių publikacijų paieška atlikta naudojantis PubMed paieškos sistema elektroninėje Medline duomenų bazëje. Atrinkti straipsniai, parašyti anglų kalba. Rezultatai. Akių cheminiai nudegimai dažniausiai ịvyksta buityje, rečiau - darbo vietoje: pramonès įmonèse, statybvietèse. Šarmai du kartus dažniau nei rūgštys sukelia cheminius akių nudegimus. Cheminès medžiagos pažeidžia akiụ junginès ir ragenos epiteli, limbo kamienines ląsteles, skverbiasi gilyn ị akies audinius ir sukelia jų negrịžtamą pažeidimą. Autoriai nurodo, kad pacientams po akių cheminių nudegimų būtina nedelsiant suteikti pirmają pagalbą, nes laiku pradètas gydymas turi įtakos gijimo eigai ir padeda išvengti sunkių pasekmių. Medikamentinio gydymo tikslas - slopinti uždegimą ir skatinti audinių regeneraciją. Aprašomi chirurginio gydymo metodai, tokie kaip amniono membranos transplantacija, limbo kamieninių ląstelių transplantacija ir kiti, kurie gali būti taikomi ir ankstyvosios, ir vèlyvosios gijimo fazès metu. Glaukoma po akių nudegimų gali pasireikšti bet kuriuo metu, todèl būtina pastoviai stebèti akispūdį. Išvados. Laiku ir teisingi paciento ir mediku veiksmai gali turèti lemiamos įtakos cheminių nudegimų baigčiai. Cheminių akių nudegimų gydymas yra didelis iššūkis kiekvienam oftalmologui, nes sunkių nudegimų atvejais regos prognozè nepalanki.
\end{abstract}

\section{Ivadas}

Kiekvienas cheminio akies nudegimo atvejis - ypač ūmi būklè, kurią būtina skubiai įvertinti ir gydyti. Greitai ir efektyviai po nudegimo nustatyta diagnozè ir pradètas gydymas gali turèti ịtakos klinikinei eigai ir padeda išvengti tragiškų pasekmių. Cheminių akių nudegimų sunkumas priklauso nuo cheminès medžiagos rūgštingumo $(\mathrm{pH})$, patekusio kiekio, kontakto su akies audiniais trukmès ir toksiškumo, todèl gydytojas oftalmologas turi parinkti pacientui specifini gydymą pagal akių cheminio nudegimo sunkumo laipsnį [1]. Ypač sunkūs yra šarmų sukelti akių nudegimai. Šarminès medžiagos pasižymi lipofilinèmis savybėmis, todèl šarmai greičiau nei rūgštys prasiskverbia pro ląstelių membranas [2]. Cheminių akių nudegimų gijimo procesas dažnai būna komplikuotas dèl uždegimo, sunkiai gyjančių epitelio defektų, limbo kamieninių ląstelių nepakankamumo, padidejusio akispūdžio [1,3], todèl šių pacientų gydymas iki šiol išlieka aktuali problema oftalmologams.

Tyrimo tikslas - išanalizuoti cheminių akių nudegimų epidemiologiją, klinikinès eigos ypatumus ir gydymo principus.

\section{Tyrimo medžiaga ir metodai}

Mokslinių publikacijų paieška atlikta naudojantis $\mathrm{Pu}-$ bMed paieškos sistema elektroninejje Medline duomenų bazèje. Atrinkti straipsniai, parašyti anglų kalba. Tyrimui gautas LSMU bioetikos centro leidimas (Nr. BEC-LSMU(R) - 41).

\section{Tyrimo rezultatai}

Epidemiologija (suaugusiųjų). J. Hong nustate, kad šarmai sukèlè sunkius akių cheminius nudegimus 70 proc. stacionarizuotų pacientų [2]. Cheminius akių nudegimus pacientai dažniausiai patyrè darbo vietoje [3]. Epidemiologinio tyrimo apie cheminius akių sužalojimus Jungtinèse Amerikos Valstijose (JAV) duomenimis, 75 proc. akių cheminius nudegimus patyrusių pacientų buvo gamyklų darbininkai ir statybininkai, kurie darbo metu nedèvèjo apsauginių akinių [4]. M. White ir bendraautorių aprašyto tyrimo metu buvo ištirti 15865 cheminių akių nudegimų atvejai per vienerius metus [4]. Jungtinejje Karalysteje atlikto tyrimo metu buvo nustatyta, kad per pusę metų ịvyko 56 akių cheminių nudegimų atvejai vienam milijonui gyventojų [5]. Dažniausiai akių cheminus sužalojimus patyrè jauni vyrai, kurių amžiaus vidurkis buvo 32 metai [6].

Epidemiologija (vaikų). R. Haring ir bendraautorių duomenimis, akių cheminius nudegimus dažniau patyre 1-2 metų vaikai (atitinkamai 28,61 ir 23,49 atvejai 100000 gyventojų) 
[6]. Indijoje atliktame tyrime dalyvavo 134 cheminius akiu nudegimus patyrę vaikai, kurių amžius buvo nuo $1,2 \mathrm{iki}$ 15,5 metų. Pusè $(51,4$ proc.) visų tiriamujų buvo 0-5 metų amžiaus grupejje, o 63,4 proc. visų tirtų pacientų buvo vyriškos lyties [7].

Cheminių akių nudegimų etiologija. Akių cheminių nudegimų sunkumas priklauso nuo cheminès medžiagos rūgštingumo $(\mathrm{pH})$, patekusio jos kiekio, kontakto su akies audiniais trukmès ir toksiškumo. Cheminius akių nudegimus dažniausiai sukelia šarmai, rečiau - rūgštys ir iritantai.

Kontakto su akies paviršiumi plote rūgštis denatūruoja ir koaguliuoja ragenos baltymus, kurie tampa tarsi barjeru gilesniam rūgšties skverbimuisi į akies audinius. J. McCulley nurodo, kad cheminius akių nudegimus dažniausiai sukelia sieros rūgštis. Jei ị akis ịtiško sieros rūgšties sprogus baterijai arba akumuliatoriui, akių pažeidimas būna sunkesnis (dèl išsiskyrusios šilumos sukeliamas ir terminis nudegimas). Skirtingai nuo kitų rūgščių, hidrofluorido rūgštis (HF) pasižymi stipriu ląsteliu membranas tirpdančiu poveikiu ir šarmams būdinga savybe - greitu skverbimusi ị akies priekinę kamerą [8].

Šarmai (natrio hidroksidas, amoniakas, kalcio hidroksidas ir kiti) pasižymi lipofiliškumu, todèl greitai ir giliai skverbiasi pro ląstelių membranas, saponifikuoja jų lipidus. Šarmo hidroksilo jonai suardo ragenos stromos matricą, taip palengvindami chemikalo skverbimąsi pro rageną i akies priekinę kamerą. Skverbimosi gylis priklauso nuo katijono savybių: amoniakas skverbiasi giliausiai, natris ir kalis mažiau, kalcis - mažiausiai. S. Brodovsky ir bendraautoriu duomenimis, iš visų šarmų akių cheminius nudegimus dažniausiai sukelia kalkinis skiedinys [9].

Akių cheminių sužalojimų klasifikacija. Klininèje praktikoje plačiai taikoma Roper - Hall klasifikacija [10]. Ši klasifikacija remiasi dviem kriterijais - ragenos pažeidimu ir limbo išemija (1 lentelè).

1 lentelè. Roper-Hall klasifikacija [10].

\begin{tabular}{|l|c|c|c|}
\hline $\begin{array}{l}\text { Laips- } \\
\text { nis }\end{array}$ & $\begin{array}{c}\text { Pro- } \\
\text { gnozé }\end{array}$ & Ragena & Limbas \\
\hline I & Gera & $\begin{array}{c}\text { Ragenos epitelio } \\
\text { pažeidimas }\end{array}$ & Nera išemijos \\
\hline II & Gera & $\begin{array}{c}\text { Lokalus ragenos stromos } \\
\text { drumstumas }\end{array}$ & $<1 / 3$ išemija \\
\hline III & $\begin{array}{c}\text { Paten- } \\
\text { kinama } \\
\text { (abejo- } \\
\text { tina) }\end{array}$ & $\begin{array}{c}\text { Visiškas epitelio praradi- } \\
\text { mas, stromos drumstejimas, } \\
\text { tačiau dar ǰžiūrimi rainelès } \\
\text { kontūrai }\end{array}$ & $\begin{array}{c}1 / 3-1 / 2 \\
\text { išemija }\end{array}$ \\
\hline IV & $\begin{array}{c}\text { Bloga } \\
\text { Ragena drumsta, balta. } \\
\text { Gilesniun akies terpių } \\
\text { nematyti }\end{array}$ & $>1 / 2$ išemija \\
\hline
\end{tabular}

H. Dua ir bendraautoriai pasiūlè naują akių cheminių nudegimų klasifikacijos sistemą (2 lentelè). Remiantis šia sistema, vertinamas junginès dažymasis fluoresceinu: limbo srities dažymasis fluoresceinu nusakomas valandomis, o akies obuolio ir skliautų junginès dažymasis - pažeisto paviršiaus ploto apimtimi, išreikšta procentais. Kiekybiškai ivertinus junginès ir limbo sužalojimo apimtị, galima apskaičiuoti analoginès skalès rezultatus [11]. Klasifikacijos trūkumas yra tas, kad nèra vertinamas ragenos pažeidimas.

Akių cheminių nudegimų klinikinès eigos fazès. Aprašomos trys akių cheminių nudegimų klinikinès eigos fazès. Pirmoji fazè trunka pirmąsias septynias dienas ir vadinama ūmia. Antroji - ankstyvoji fazè, trunkanti iki 21 paros. Ši fazè dar vadinama tranzitine, nes jos metu lengvų nudegimu atvejais įvyksta visiška akies paviršiaus reepitelizacija ir pacientas pasveiksta. Sunkių nudegimų atvejais šios fazès metu vyrauja akių uždegimas, prasideda ragenos nekrozé, stebima sutrikusi akies paviršiaus regeneracija. Trečioji vèlyvoji fazè, kuri prasideda po akies nudegimo praejus trims savaitėms. Šios fazės metu stebimi persistuojantys ragenos epitelio defektai, lètinis uždegimas, ragenos stromos drumstejimas ir vaskuliarizacija, vystosi katarakta, antriné glaukoma. Akispūdžio pakilimas gali pasireikšti bet kurios klinikinès eigos fazès metu, todèl būtina nuolatinè akispūdžio kontrolè [10].

2 lentelė. H. Dua ir kt. klasifikacija [11].

\begin{tabular}{|l|c|c|c|c|}
\hline $\begin{array}{l}\text { Laips- } \\
\text { nis }\end{array}$ & $\begin{array}{c}\text { Pro- } \\
\text { gnoze }\end{array}$ & $\begin{array}{c}\text { Klinikiniai } \\
\text { radiniai }\end{array}$ & $\begin{array}{c}\text { Junginės } \\
\text { pažeidimas }\end{array}$ & $\begin{array}{c}\text { Analogü } \\
\text { skalė }\end{array}$ \\
\hline I & $\begin{array}{c}\text { Labai } \\
\text { gera }\end{array}$ & $\begin{array}{c}0 \text { val. limbo } \\
\text { pažeidimas }\end{array}$ & $0 \%$ & $0 / 0 \%$ \\
\hline II & Gera & $\begin{array}{c}\leq 3 \text { val. limbo } \\
\text { pažeidimas }\end{array}$ & $\leq 30 \%$ & $0,1-3 / 1-29,9 \%$ \\
\hline III & Gera & $\begin{array}{c}>3-6 \text { val. } \\
\text { limbo pažei- } \\
\text { dimas }\end{array}$ & $>30-50 \%$ & $3,1-6 / 31-50 \%$ \\
\hline IV & $\begin{array}{c}\text { Nuo } \\
\text { geros } \\
\text { iki kon- } \\
\text { troliuo- } \\
\text { jamos }\end{array}$ & $\begin{array}{c}>6-9 \text { val. } \\
\text { limbo pažei- } \\
\text { dimas }\end{array}$ & $>50-75 \%$ & $6,1-9 / 51-75 \%$ \\
\hline $\begin{array}{c}\text { Nuo } \\
\text { kontro- } \\
\text { liuoja- } \\
\text { mos iki } \\
\text { blogos }\end{array}$ & $\begin{array}{c}>9-<12 \text { val. } \\
\text { limbo pažei- } \\
\text { dimas }\end{array}$ & $>75-<100 \%$ & $9,1-11,9 / 75,1-$ \\
\hline VI & $\begin{array}{c}\text { Labai } \\
\text { prasta }\end{array}$ & $\begin{array}{c}\text { Visiškas } \\
\text { limbo pažei- } \\
\text { dimas (12 } \\
\text { val.) }\end{array}$ & $\begin{array}{c}\text { Visiškas } \\
\text { jungines } \\
\text { pažeidimas } \\
100 \%\end{array}$ & $12 / 100 \%$ \\
\hline
\end{tabular}


Akių cheminių nudegimų gydymas. Pirmoji pagalba - kuo skubesnis akių plovimas vandeniu iš bet kokio prieinamo vandens šaltinio. Akis plauti reikia ne trumpiau kaip 30 minučių ir tik tuomet pacientas turi vykti ị gydymo ịstaigą, kur jam bus suteikta būtinoji pagalba.

Gydymo įstaigoje akių plovimas tęsiamas. İ junginès maišą ịlašinama anestetikų akių lašų, įdedamas Morgano lęšis, kuris sujungiamas su intraveninio lašinimo sistema. Akių plovimui gali būti naudojami įvairūs injekciniai tirplai - izotoninis druskos tirpalas $(0,9$ proc. $\mathrm{NaCl})$, balansuotas druskų tirpalas (BSS), Ringerio laktatas arba Difoterino buferinis tirpalas. Akiu plovimas tęsiamas, kol atsikuria atkuriamas akies paviršiaus rūgštingumas $(\mathrm{pH} 7,4-7,6)$. Jei i j akis pateko kietų cheminių medžiagų (pvz. kalkinio skiedinio), atlikus dvigubą vokų vertimą, pirmiausia reikia mechaniškai pašalinti visas kietas daleles [12].

Ūmioje akių cheminių nudegimų fazeje epitelio regeneracijos skatinimui naudojami drèkinamieji akių lašai be konservantų [10].

Po cheminių nudegimų priekinès kameros skystyje reikšmingai sumažèja askorbato kiekis. Askorbatas itin svarbus ragenos stromoje vykstančiai kolageno sintezei [13]. Akorbato trūkumas priekinės kameros skystyje didina ragenos išopėjimo ir perforacijos riziką [14]. Kolageno produkcijos skatinimui visų klinikinès eigos fazių metu askorbatas gali būti skiriamas tiek vietiškai, tiek sistemiškai.

Bakterinès infekcijos profilaktikai skiriami plataus spektro antibiotikų akių lašai. Peroraliai skiriami tetraciklinų derivatai (pvz. doksiciklinas po $100 \mathrm{mg} 2$ kartus per dieną). Šios grupès antibiotikai mažina kolagenazès ir polimorfobranduolinių leukocitų aktyvumą, mažindami ragenos išopejjimo riziką [10].

Žmogaus amniono membranos transplantacija (AMT) gali būti taikoma ūmios fazès metu. Amniono membrana pasižymi epitelizaciją gerinančiomis ir uždegimą mažinančiomis savybèmis [15]. R. Tandon ir kt. tyrimo duomenimis, pacientų, kuriems po akių cheminių nudegimų buvo taikomas medikamentinis gydymas ir atlikta AMT, ragenos reepitelizacija buvo reikšmingai greitesnè negu pacientų, kuriems buvo paskirtas tik medikamentinis gydymas [16].

Po sunkių cheminių nudegimų pacientams gali išsivystyti limbo kamieninių ląstelių nepakankamumas, todèl rekomenduojama atlikti limbo kamieninių ląstelių transplantaciją. Naudojami alogeniniai donoro (gyvo arba mirusio) arba autologiniai (paciento sveikosios akies) limbo transplantatai [17].

Atviro kampo glaukoma - dar viena dažna akių cheminių nudegimų komplikacija. S. Choi ir kt. nurodo, kad pacientams, kurių akispūdis po akių cheminių nudegimų buvo daugiau kaip $21 \mathrm{mmHg}$, buvo 151,2 karto didesnè glaukomos išsivystymo rizika [18]. Taikomas medikamentinis glauko- mos gydymas karboanhidrazès inhibitorių, betaadrenoblokatorių, alfaagonistų akių lašais. Glaukomai progresuojant, gali būti atliekama trabekulektomija, šunto implantavimo operacija, ciklofotokoaguliacija, krioterapija [12].

\section{Išvados}

1. Laiku atliekami tinkami paciento ir medikų veiksmai gali turèti lemiamos įtakos cheminių nudegimų baigčiai.

2. Cheminių akių nudegimų medikamentinio gydymo tikslas - skatinti audinių regeneraciją ir slopinti uždegimą.

3. Cheminių akių nudegimų chirurginis gydymas - audinių transplantacija, net ir tobulejant operacijos technikoms ir plečiantis galimybėms, yra didelis iššūkis kiekvienam oftalmologui, nes sunkių nudegimų atvejais regos prognozė nepalanki.

\section{Literatūra}

1. Syngh P, Tyagi M, Kumar Y, Gupta KK, Sharma P D. Ocular chemical injuries and their management. Oman J Ophthalmol 2013;6(2):83-86.

https://doi.org/10.4103/0974-620X.116624

2. Hong J, Qiu T, Wei A, Sun X, Xu J. Clinical characteristics and visual outcome of severe ocular chemical injuries in Shanghai. Ophthalmology 2010;117(12):2268-72.

https://doi.org/10.1016/j.ophtha.2010.03.050

3. Xiang H, Stallones L, Chen G, Smith GA. Work-related eye injuries treated in hospital emergency departments in the US. Am J Ind Med 2005;48(1):57-62.

https://doi.org/10.1002/ajim.20179

4. White ML, Chodosh J, Jang J, Dohlman C. Incidence of StevensJohnson syndrome and chemical burns to the eye. Cornea 2015;34(12):1527-33.

https://doi.org/10.1097/ICO.0000000000000646

5. Ghosh S, Salvador-Culla B, Kotagiri A, Pushpoth S, Tey A, Johnson ZK, et al. Acute chemical eye injury and limbal stem cell deficiency-a prospective study in the United Kingdom. Cornea 2019;38(1):8-12.

https://doi.org/10.1097/ICO.0000000000001739

6. Haring RS, Sheffield ID, Channa R, Canner JK, Schneider EB. Epidemiologic trends of chemical ocular burns in the United States. JAMA Ophthalmol 2016;134(10):1119-1124.

https://doi.org/10.1001/jamaophthalmol.2016.2645

7. Vajpayee RB, Shekhar H, Sharma N, Jhanji V. Demographic and clinical profile of ocular chemical injuries in the pediatric age group. Ophthalmology 2014;121(1):377-380. https://doi.org/10.1016/j.ophtha.2013.06.044

8. McCulley JP. Ocular hydrofluoric acid burns: animal model, mechanism of injury and therapy. Trans Am Ophthalmol Soc 1990;88:649-84.

9. Brodovsky SC, McCarty CA, Snibson G, Loughnan M, Sullivan L, Daniell M, et al. Management of alkali burns: an 11-year 
retrospective review. Ophthalmology 2000;107(10):1829-35. https://doi.org/10.1016/S0161-6420(00)00289-X

10. Bizrah M, Yusuf A, Ahmad S. An update on chemical eye burns. Eye (Lond) 2019;33(9):1362-1377. https://doi.org/10.1038/s41433-019-0456-5

11. Dua HS, King AJ, Joseph A. A new classification of ocular surface burns. Br J Ophthalmol 2001;85(11):1379-83.

https://doi.org/10.1136/bjo.85.11.1379

12. Sharma N, Kaur M, Agarwal T, Sangwan VS, Vajpayee RB, Treatment of acute ocular chemical burns. Survey of Ophthalmology 2018;63(2):214-235.

https://doi.org/10.1016/j.survophthal.2017.09.005

13. Pfister RR, Paterson CA. Ascorbic acid in the treatment of alkali burns of the eye. Ophthalmology 1980;87(10):1050-7.

https://doi.org/10.1016/S0161-6420(80)35126-9

14. Petroutsos G, Pouliquen Y. Effect of ascorbic acid on ulceration in alkali-burned corneas. Ophthalmic Res 1984;16(4):185-9. https://doi.org/10.1159/000265322

15. Clare G, Suleman H, Bunce C, Dua H. Amniotic membrane transplantation for acute ocular burns. Cochrane Db Syst Rev 2012; 12;(9): CD009379.

https://doi.org/10.1002/14651858.CD009379.pub2

16. Tandon R, Gupta N, Kalaivani M, Sharma N, Titiyal JS, Vajpayee RB. Amniotic membrane transplantation as an adjunct to medical therapy in acute ocular burns. Brit J Ophthalmol 2011;95(2):199-204.

https://doi.org/10.1136/bjo.2009.173716

17. Shanbhag SS, Saeed HN, Paschalis EI, Chodosh J. Keratolimbal allograft for limbal stem cell deficiency after severe corneal chemical injury: a systematic review. Br J Ophthalmol 2018;102(8):1114-1121.

https://doi.org/10.1136/bjophthalmol-2017-311249

18. Choi SH, Kim MK, Oh JY. Glaucoma after ocular chemical burns: incidence, risk factors, and outcome. Sci Rep 2020;10(4763).

https://doi.org/10.1038/s41598-020-61822-5

\section{CHEMICAL OCULAR BURNS}

K. Sauliūnaitė, E. Puodžiuvienė

Keywords: ocular chemical burn, ocular chemical burn treatment, eye chemical injury.

Summary

Background. The aim was to analyze the epidemiology of ocular chemical burns, the peculiarities of the clinical course and the principles of treatment.

Methods. A systematic review of the literature was performed. The search for scientific publications was performed using the $\mathrm{Pu}$ bMed search system in the electronic Medline database. Selected articles were written in English. Results. Chemical eye burns most often occur at home, less often in the workplace - in industrial enterprises, construction sites. Alkalis cause chemical burns to the eyes twice as often as acids. Chemicals cause damage to the corneal and conjunctival epithelium, limbal stem cells, penetrate deep into the eye tissues, and cause irreversible damage. The authors point out that patients must be given first aid immediately after chemical eye burns because timely treatment affects the course of healing and helps to avoid severe consequences. The goal of medical treatment is to suppress inflammation and promote tissue regeneration. The methods of surgical treatment such as amniotic membrane transplantation, limb stem cell transplantation, and others, can be applied during both the early and late phases of the clinical course. Glaucoma after eye chemical injury can occur at any time, so constant monitoring of intraocular pressure is necessary. Conclusions. Timely and correct actions by the patient and physicians can have a decisive impact on the outcome of chemical eye injury. The treatment of chemical eye burn is a major challenge for every ophthalmologist because in severe cases the visual prognosis remains unfavorable.

Correspondence to: kristinelisaul@gmail.com

Gauta 2021-03-29 